\title{
Composição química de capim-tanzânia adubado com nitrogênio e fósforo ${ }^{1}$
}

\section{Ronaldo Silva Sousa ${ }^{2}$, Aureliano José Vieira Pires ${ }^{3}$, Gleidson Giordano Pinto de Carvalho ${ }^{4}$, Fabiano Ferreira da Silva ${ }^{3}$, Albertí Ferreira Magalhães ${ }^{2}$, Cristina Mattos Veloso ${ }^{3}$}

1 Projeto financiado pela Universidade Estadual do Sudoeste da Bahia-UESB.

2 MAPA/CEPLAC/EMARC-IT, Rod.Itapetinga/Itororó, km 02, CEP: 45700-000, Itapetinga, BA.

${ }^{3}$ UESB, Itapetinga, BA. Pesquisador do CNPq.

${ }^{4}$ Doutorando em Zootecnia UFV, Viçosa, MG.

RESUMO - Avaliaram-se os teores de matéria seca (MS), proteína bruta (PB), fibra em detergente neutro (FDN), nutrientes digestíveis totais (NDT), cálcio (Ca), fósforo (P) e magnésio (Mg) na parte aérea do capim-tanzânia (Panicum maximum) adubado com nitrogênio e fósforo durante o período de verão/outono. Utilizou-se o delineamento inteiramente casualizado, em esquema fatorial $4 \times 3$, com quatro doses de nitrogênio $(0,100,200$ e $300 \mathrm{~kg} / \mathrm{ha} / \mathrm{ano})$ e três doses de pentóxido de difósforo $\left(\mathrm{P}_{2} \mathrm{O}_{5}\right)(0,50$ e $100 \mathrm{~kg} / \mathrm{ha} / \mathrm{ano})$, com três repetições. Foram realizados três cortes a $40 \mathrm{~cm}$ do solo, a cada 35 dias. Após cada corte, foi realizada adubação, aplicando-se o $\mathrm{P}_{2} \mathrm{O}_{5}$ de uma só vez no corte de uniformização e o nitrogênio parcelado em três vezes. As doses de nitrogênio não afetaram os teores de magnésio e reduziram os teores de matéria seca, cálcio e fósforo, enquanto a adubação fosfatada aumentou o teor de fósforo. A adubação teve efeito quadrático nos teores de PB, FDN e NDT, melhorando a qualidade da forragem conforme aumentaram as doses, principalmente de nitrogênio. Nas condições edafoclimáticas estudadas, recomenda-se que o capim-tanzânia seja adubado com $300 \mathrm{~kg}$ de N/ha e $100 \mathrm{~kg}$ de $\mathrm{P}_{2} \mathrm{O}_{5}$ /ha.

Palavras-chave: fibra em detergente neutro, forrageira, matéria seca, minerais, Panicum maximum, proteína bruta

\section{Chemical composition of Tanzania grass fertilized with nitrogen and phosphorus}

\begin{abstract}
It was evaluated in this work the contents of dry matter (DM), crude protein (CP), neutral detergent fiber (NDF), total digestible nutrients (TDN), calcium (Ca), phosphorus (P) and magnesium (Mg) in the aerial section of the Tanzania grass (Panicum maximum), fertilized with nitrogen and phosphorus during the summer and autumn. The experimental design was complete randomized, with a $4 \times 3$ factorial scheme, and four $\mathrm{N}$ rates $(0,100,200$, and $300 \mathrm{~kg} / \mathrm{ha} / \mathrm{year})$, and three pentoxide diphosphorus $\left(\mathrm{P}_{2} \mathrm{O}_{5}\right)$ rates $(0,50$, and $100 \mathrm{~kg} / \mathrm{ha} /$ year $)$, with three replicates. Three cuts were made at $40 \mathrm{~cm}$ of the soil, every 35 days. After each cut, the fertilization was accomplished, and $\mathrm{P}_{2} \mathrm{O}_{5}$ was applied only once on the uniformed cut and $\mathrm{N}$ was parceled in three times. Nitrogen rates did not affect contents of magnesium and they reduced contents of dry matter, calcium and phosphorus, while phosphate fertilization increased levels of phosphorus. Fertilization had a quadratic effect on the levels of crude protein, neutral detergent fiber, and total digestible nutrients providing a forage of better quality as doses increased, mainly nitrogen doses. In the studied edaphoclimathic conditions, it is recommend fertilization of Tanzania grass with $300 \mathrm{~kg}$ of $\mathrm{N} / \mathrm{ha}$ and $100 \mathrm{~kg}$ of $\mathrm{P}_{2} \mathrm{O}_{5} / \mathrm{ha}$.
\end{abstract}

Key Words: crude protein, dry matter, minerals, neutral detergent fiber, Panicum maximum, roughage

\section{Introdução}

A produtividade média das pastagens brasileiras é bastante baixa, devido, principalmente, ao manejo inadequado e à pouca fertilidade do solo. No entanto, o potencial de produção das gramíneas tropicais dos gêneros Panicum e Brachiaria é bastante alto, desde que sejam feitas correções e adubações do solo.
O processo produtivo das plantas forrageiras passa necessariamente pelo suprimento de suas exigências nutricionais nas fases de formação da pastagem e manutenção da produção (Almeida Neto, 1992). A maioria das forrageiras apresenta desbalanço nutricional, fator que limita o desempenho animal. É importante que, na exploração racional da pecuária, os pastos sejam de alto valor nutritivo, proporcionando alimentação ideal, com custo financeiro

Recebido em 12/3/2008 e aprovado em 29/5/2009. 
adequado. O estudo do valor nutritivo da forragem contribui para a identificação dos fatores limitantes ao consumo de nutrientes e, consequentemente, a produção animal (Brâncio et al., 2002).

O fósforo e o nitrogênio são os principais nutrientes limitantes à produtividade de pastagens. O fósforo atua no metabolismo das plantas, desempenhando papel importante na transferência de energia da célula, na respiração e na fotossíntese (Grant \& Flaten, 2001). A resposta à adubação fosfatada depende, entre outros fatores, da disponibilidade de fósforo no solo, da disponibilidade de outros nutrientes, como o nitrogênio e o potássio, da espécie e das condições climáticas (Sousa et al., 2004). O nitrogênio é o principal nutriente para manutenção da produtividade das gramíneas forrageiras (Werner, 1994), e, como parte da molécula da clorofila, participa diretamente da fotossíntese (Sousa \& Lobato, 2004). De acordo com Cantarutti et al. (1999b), a adubação nitrogenada é fundamental para a sustentabilidade das pastagens, desde que seja assegurada adequada disponibilidade de fósforo.

A cultivar tanzânia, espécie Panicum maximum, foi lançada comercialmente em 1990, pela EMBRAPA Gado de Corte. Apesar de ser bastante difundida em todas as regiões do Brasil, suas características produtivas ainda são pouco conhecidas (Santos et al., 1999). Assim, realizou-se este trabalho com o objetivo de avaliar a qualidade do capim-tanzânia adubado com nitrogênio e pentóxido de difósforo $\left(\mathrm{P}_{2} \mathrm{O}_{5}\right)$.

\section{Material e Métodos}

O experimento foi realizado no período de 3/2/2002 a 27/4/2002, em uma área de pastagem implantada de capim Panicum maximum cv. Tanzânia-1 desde dezembro de 1999 e, de acordo com a análise química do solo, não houve necessidade de calagem nem de potassagem. O clima é do tipo “Cw” Mesotérmico úmido e subúmido, quente com inverno seco, pela classificação de Köppen.

Em dezembro de 2001 foram coletadas amostras de solo, classificado texturalmente como franco argilo-arenoso, à profundidade de 0 a 20 cm (Cantarutti et al., 1999a), para análises química e física, a qual indicou as seguintes características químicas: $\mathrm{pH}$ em $\mathrm{H}_{2} \mathrm{O}=5$,8; matéria orgânica = $41 \mathrm{~g} / \mathrm{dm}^{3}$; fósforo $($ Mehlich 1$)=12 \mathrm{mg} / \mathrm{dm}^{3}$; potássio $=$ $0,26 \mathrm{cmol}_{\mathrm{c}} / \mathrm{dm}^{3} ;$ cálcio $=6,6 \mathrm{cmol}_{\mathrm{c}} / \mathrm{dm}^{3} ;$ magnésio $=$ $1,6 \mathrm{cmol}_{\mathrm{c}} / \mathrm{dm}^{3} ; \mathrm{H}+\mathrm{Al}=3,1 \mathrm{cmol}_{\mathrm{c}} / \mathrm{dm}^{3} ;$ alumínio $=$ $0,1 \mathrm{cmol}_{\mathrm{c}} / \mathrm{dm}^{3}$; capacidade de troca de cátions (CTC) = $11,5 \mathrm{cmol}_{\mathrm{C}} / \mathrm{dm}^{3}$; e saturação por bases $(\mathrm{V})=73 \%$. As características físicas apresentaram a seguinte proporção:
320 g/kg de argila, 210 g/kg de areia grossa, 310 g/kg de areia fina e $160 \mathrm{~g} / \mathrm{kg}$ de silte.

Foi utilizado o esquema fatorial $4 \times 3$, com quatro doses de nitrogênio (0, 100, 200 e $300 \mathrm{~kg}$ de N/ha/ano) e três de $\mathrm{P}_{2} \mathrm{O}_{5}$ (0, 50 e $100 \mathrm{~kg}$ de $\mathrm{P}_{2} \mathrm{O}_{5} /$ ha/ano), distribuídos em delineamento inteiramente casualizado em parcelas que de

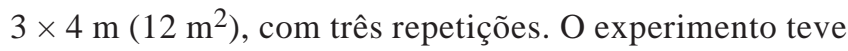
início em 3 de fevereiro de 2002, época em que ocorreu o corte de uniformização, a $40 \mathrm{~cm}$ do solo, em todas as parcelas, e o material cortado foi retirado imediatamente da área. Logo após, foi feita a primeira adubação das parcelas. A segunda e terceira adubações foram realizadas após cada corte utilizando-se sulfato de amônio (20\% de nitrogênio e $24 \%$ de S) como fonte nitrogenada e superfosfato simples (20\% de $\mathrm{P}_{2} \mathrm{O}_{5}$ e $12 \%$ de $\mathrm{S}$ ), como fonte fosfatada.

A cada 35 dias foram realizados três cortes a $40 \mathrm{~cm}$ do solo, seguidos de adubação. Após cada corte, o material coletado em cada parcela foi pesado e, em seguida, foram retiradas amostras representativas da parte aérea, que foram devidamente identificadas e secas em estufa de ventilação forçada a $\pm 60^{\circ} \mathrm{C}$ por 72 horas (Silva \& Queiroz, 2002). Após o terceiro e último corte, todas as amostras foram secas para futuras análises laboratoriais.

Foram avaliados os teores de matéria seca (MS), proteína bruta (PB), fibra em detergente neutro (FDN), cálcio, fósforo e magnésio. As análises foram realizadas conforme procedimento descrito por Silva \& Queiroz (2002).

A estimativa dos teores de NDT das forragens foi feita a partir da equação de regressão, $\mathrm{Y}=83,79-0,4171$ FDN ( $\left.\mathrm{R}^{2}=0,82 ; \mathrm{P}<0,01\right)$ (Cappelle et al., 2001). As análises de fósforo foram feitas pelo método colorimétrico, segundo Fiske \& Subbarow (1925), e as de cálcio e magnésio, por espectrofotômetro de absorção atômica (Fick et al., 1979).

Foram testados modelos de regressão linear múltipla, e escolhido o mais adequado observando a significância das variáveis pelo teste t, a 5\% de probabilidade, e com base no coeficiente de determinação, utilizando-se o programa SAEG - Sistema de Análises Estatísticas e Genéticas (Ribeiro Jr., 2001).

\section{Resultados e Discussão}

A combinação de nitrogênio e fósforo não influenciou o teor de MS, mas teve efeito linear decrescente sobre o teor de matéria seca (Figura 1). As médias observadas, quando usadas doses de $\mathrm{P}_{2} \mathrm{O}_{5}$, foram 25,6 e 25,8\% de MS para as doses de 0, 50 e 100 kg/ha. Com a adubação nitrogenada, houve pequeno declínio nos teores de MS à medida que se aumentaramas doses dos adubos. As médias encontradas 


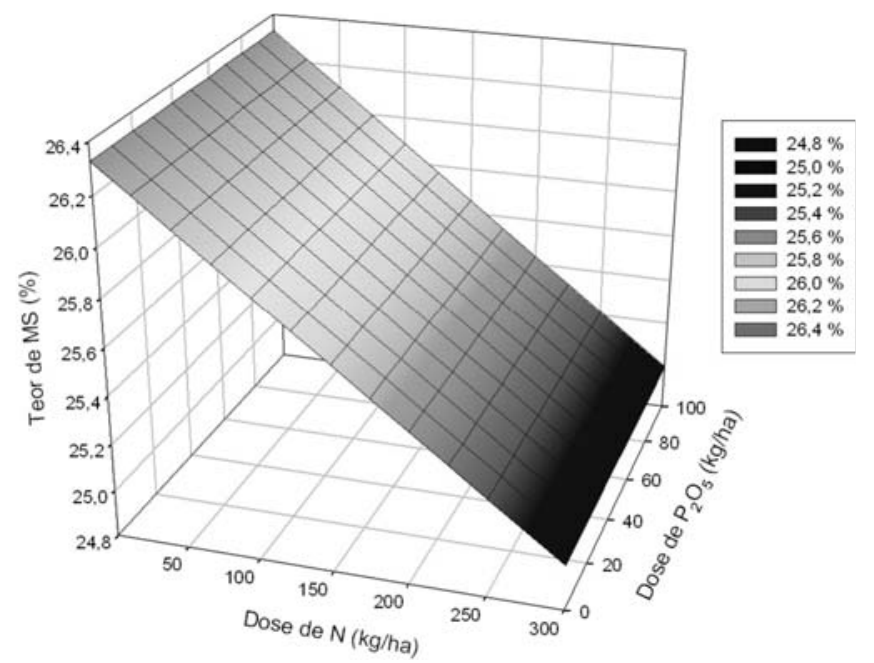

$\hat{Y}=26,3267-0,00445731 * x N, R^{2}=0,50$

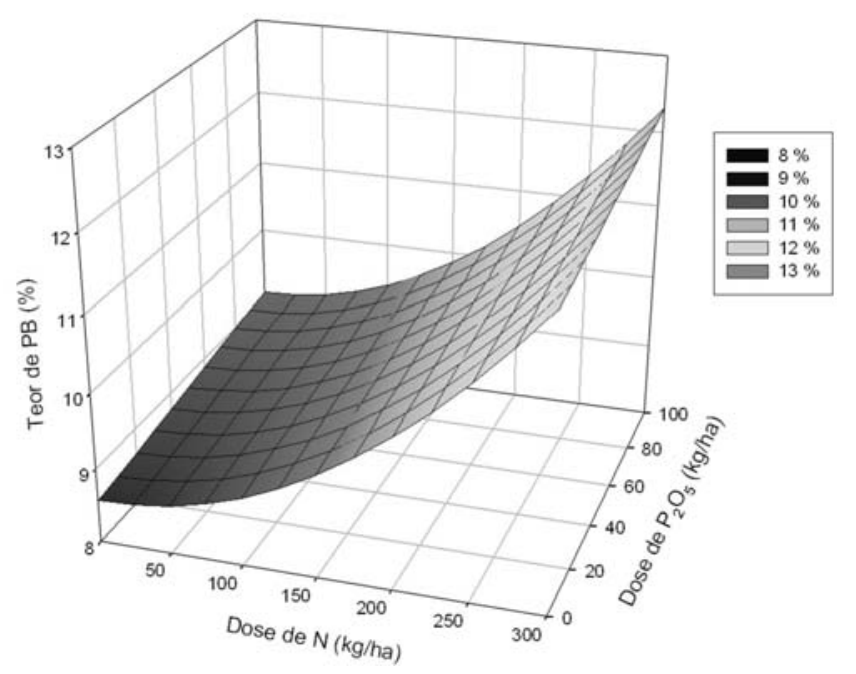

$\hat{Y}=8,56472-0,0002 * x N+0,0000366667 * * x N^{2}+0,00508333 * * x P, R^{2}=0,94$

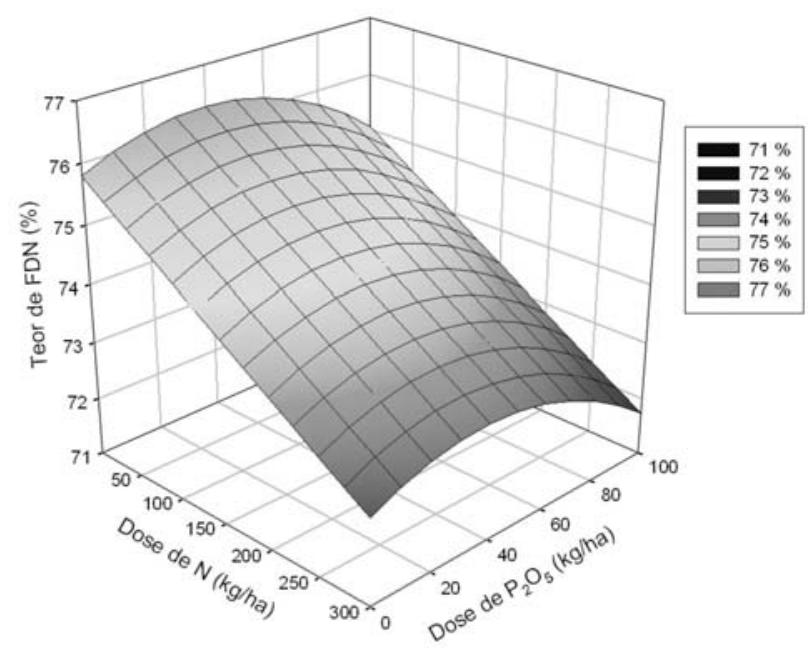

$\hat{Y}=75,79-0,0111 * * x N+0,0266667 x P-0,00034 * x P^{2}, R^{2}=0,86$

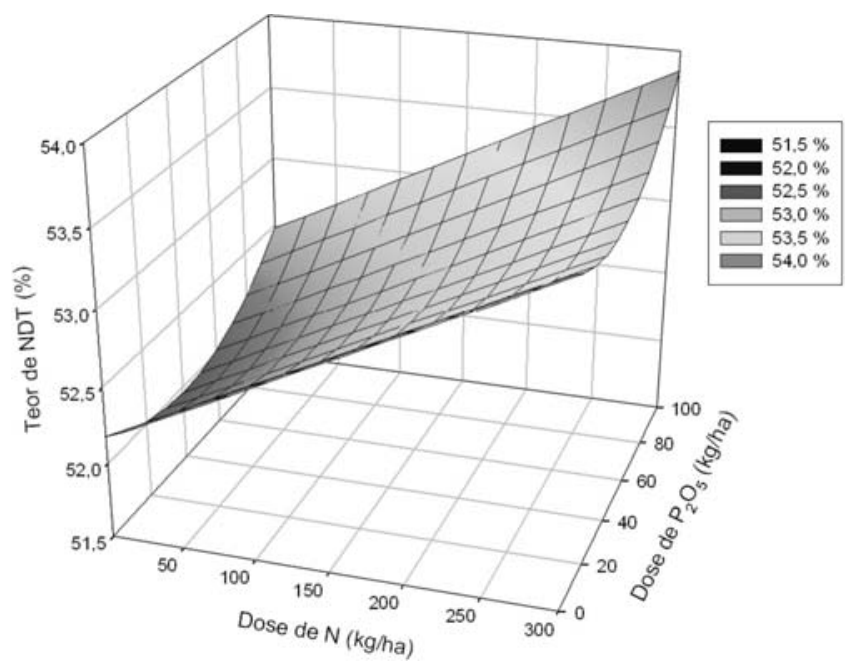

$\hat{Y}=52,178+0,00462981 * * x N-0,0111227 x P+0,000141814 * x P^{2}, R^{2}=0,86$

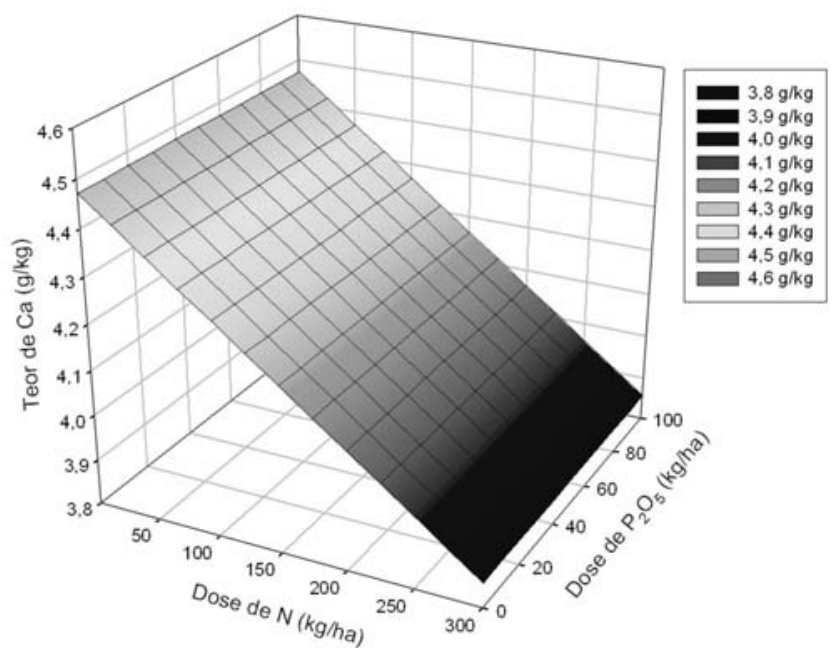

$\hat{Y}=4,47111-0,00205 * * x N, R^{2}=0,76$

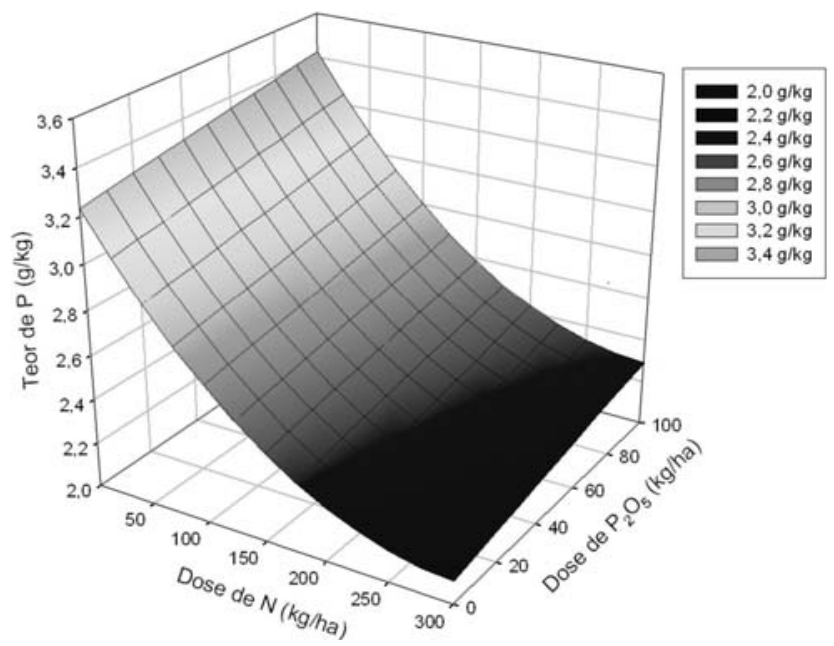

$\hat{Y}=3,23341-0,00742478 * * x N+0,0000121722 * * x N^{2}+0,00190667 * x P, R^{2}=0,91$

Figura 1 - Teores de matéria seca (MS), proteína bruta (PB), fibra em detergente neutro (FDN), nutrientes digestíveis totais (NDT), cálcio (Ca), fósforo $(\mathrm{P})$ e magnésio $(\mathrm{Mg})$ em capim-tanzânia adubado com $\mathrm{P}_{2} \mathrm{O}_{5}$ e nitrogênio em três idades de corte. 


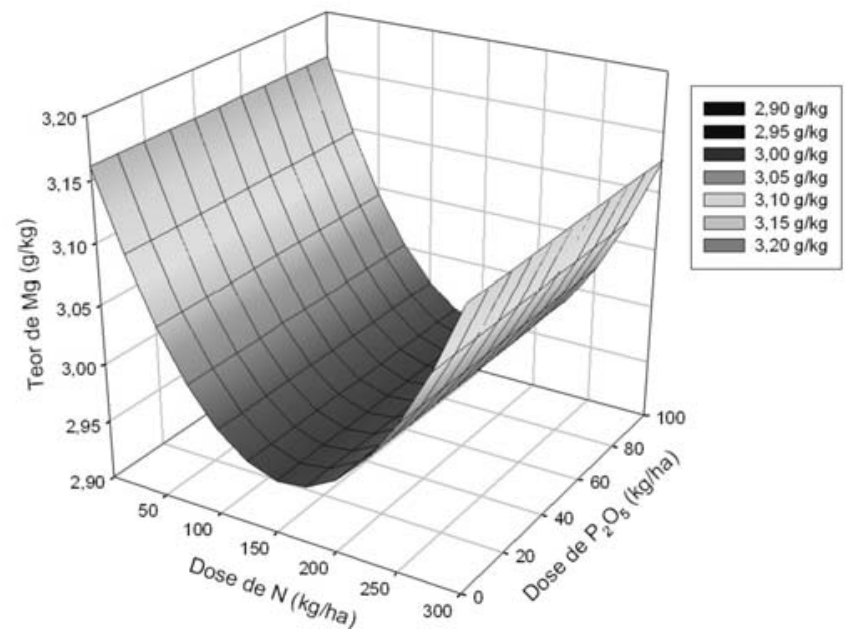

$\hat{Y}=3,16072-0,00277056 * x N+0,00000886111 * x N^{2}, R^{2}=0,97$

foram de 26,2; 25,7; 26,2 e 24,5\% de MS para as doses de 0, 100, 200 e $300 \mathrm{~kg} \mathrm{~N} / \mathrm{ha}$, respectivamente, determinando teor médio, em todos os tratamentos, de 25,7\%. Esse resultado está próximo ao encontrado por Valadares Filho et al. (2002), que, com base em diversos trabalhos realizados no Brasil, encontraram média de 27,3\% de MS, com desvio de 5,02 em forragem verde de Panicum maximum cv. Tanzânia, superior aos encontrados por Santos et al. (2003), que, avaliando o potencial produtivo e a composição química de cinco gramíneas tropicais adubadas após cada corte, encontraram, para o capim tanzânia, média de 19,2\% de MS durante o período primavera-outono. Provavelmente, esse valor esteve relacionado às adubações utilizadas, aliadas ao uso da irrigação, permitindo maior proporção de folhas $(96,0 \%)$ em relação à forragem total produzida.

Resultados semelhantes também foram encontrados por Gerdes et al. (2000), que avaliaram as características agronômicas e morfológicas das gramíneas marandu, setária e tanzânia aos 35 dias de idade de crescimento nas estações do ano e observaram no capim-tanzânia teores de MS de $16,9 \%$ (outono) a 22,9\% (inverno), enquanto no verão o valor médio foi de 19,3\%. Baixos teores de MS em gramíneas é um dos fatores que limitam o consumo pelos animais (Euclides, 1995).

O teor de $\mathrm{PB}$ apresentou comportamento quadrático em resposta às doses de nitrogênio e $\mathrm{P}_{2} \mathrm{O}_{5}$ (Figura 1 ). A partir da equação encontrada, foi possível estimar teores de $8,6 \%$ de PB na testemunha, e de $12,3 \%$, quando foram utilizadas as doses máximas de nitrogênio e $\mathrm{P}_{2} \mathrm{O}_{5}$.

Esses resultados, em parte, podem estar associados à alta relação folha/haste, que foi de 3,6, e ao intervalo de corte, de 28 dias, que favorecem a manutenção de folhas e colmos jovens, e estão de acordo com relatos de Machado et al. (1998), que, avaliando a composição química e a digestibilidade de vários cultivares e acessos de Panicum maximum sob duas alturas de corte, encontraram teores médios de 11,8 e 12,1\% de PB para o capim-tanzânia nas alturas de 20 e $40 \mathrm{~cm}$, respectivamente.

Os resultados deste trabalho foram inferiores aos reportados por Balsalobre et al. (2003), que, simulando o pastejo de capim-tanzânia em área irrigada, por meio de amostras coletadas ao longo de um ano, observaram tendência de aumento na composição protéica ao longo do ano, variando de 11,3 a 14,6\% de PB, provavelmente devido às correções de solo para garantir saturação por bases de $80 \%$, fósforode $30 \mathrm{mg} / \mathrm{dm}^{3}$ e potássio de $5 \%$ da CTC, e às adubações nitrogenada (80 kg de N/ha/pastejo) e potássica (80 kg de $\mathrm{K}_{2} \mathrm{O} /$ ha/pastejo) realizadas em todos os ciclos de pastejo durante o período experimental. Por outro lado, foram superiores aos encontrados por Santos et al. (2003), que, trabalhando com diversas espécies forrageiras para avaliar o desempenho produtivo e qualitativo, observaram para o cultivar Tanzânia cortado aos 35 dias de idade valores de 7,2\% de PB, média de seis cortes.

Em todas as combinações, o capim apresentou teores de PB superiores a 7\% de na MS, considerado nível crítico (Van Soest, 1994), visto que, abaixo desse nível, ocorreria restrição ao consumo voluntário, por reduzir a atividade de microrganismos no rúmen e a taxa de digestão de celulose, aumentando o tempo de retenção da forragem no rúmen.

Não houve efeito de nenhuma das combinações de nitrogênio e de $\mathrm{P}_{2} \mathrm{O}_{5}$ sobre o teor de $\mathrm{FDN}$, cujo comportamento foi quadrático (Figura 1). Os teores médios foram de 75,9; 74,0; 74,0 e 72,2\%, para 0, 100, 200 e $300 \mathrm{~kg}$ de N/ha, respectivamente.

Essas médias de FDN encontradas para a parte aérea do capim-tanzânia são altas, o que pode comprometer o valor nutritivo da forragem. Valores de constituintes de parede celular acima de 55 a $60 \%$ estão correlacionados negativamente ao consumo de forragem (Van Soest, 1965). Entretanto, estão dentro das médias, geralmente observadas em trabalhos com forrageiras tropicais. Machado et al. (1998), avaliando a composição química e a digestibilidade de vários cultivares e acessos de Panicum maximum sob duas alturas de corte, encontraram teor médio de 74,5\% de FDN para o cv. Tanzânia, na altura de $40 \mathrm{~cm}$ no período chuvoso, com 35 dias de crescimento.

Patês et al. (2009), trabalhando com capim-tanzânia adubado com nitrogênio e fósforo, também não verificaram alterações para FDN, com valores médios de 71,6\% de FDN, independentemente da adubação. Resultados 
semelhantes foram encontrados por Difante et al. (2010), que verificaram para o capim-tanzânia sob pastejo teor de $78 \%$ para FDN.

Valadares Filho et al. (2002), catalogando diversos trabalhos realizados no Brasil, encontraram média de 75,3\% de FDN, com desvio de 5,09, em forragem verde de Panicum maximum cv. Tanzânia. Santos et al. (2003), em pesquisa com diversas espécies forrageiras, avaliaram o desempenho produtivo e qualitativo, observaram, para o cultivar tanzânia cortado aos 35 dias de idade, valores de 79,2\% de FDN, média de seis cortes.

Isso pode estar relacionado ao fato de essas plantas se desenvolverem sob condições de altas temperaturas e apresentarem elevados valores de constituintes da parede celular (Van Soest, 1994), o que pode comprometer o consumo dessa gramínea, apesar da grande proporção de folhas e do bom teor protéico verificados no presente trabalho.

O teor de NDT apresentou comportamento quadrático em resposta às doses de nitrogênio e de $\mathrm{P}_{2} \mathrm{O}_{5}$ (Figura 1 ). A partir da equação, observa-se aumento do conteúdo de NDT, de 52,2\% sem adubação e de 53,9\%, para as maiores doses da adubo utilizadas, valores que se aproximam do teor médio relatado por Valadares Filho et al. (2002), que foi de 53,0\%. Entretanto, são inferiores aos encontrados por Balsalobre et al. (2003), que, simulando o pastejo de capimtanzânia em área irrigada, observaram teores calculados de NDT que variaram de 55,2 a 59,3\%, maiores na primavera e no verão, provavelmente, devido às maiores doses de nitrogênio aplicadas (800 kg de N/ha), à adubação potássica (800 kg de $\mathrm{K}_{2} \mathrm{O} / \mathrm{ha}$ ) e às correções de solo para garantir saturação por bases de $80 \%$, fósforo de $30 \mathrm{mg} / \mathrm{dm}^{3}$ e potássio de 5\% da CTC.

As doses de nitrogênio tiveram efeito linear decrescente sobre o teor de cálcio da parte aérea do capimtanzânia (Figura 1)no entanto, não foi verificado efeito das doses de $\mathrm{P}_{2} \mathrm{O}_{5}$ sobre essa variável. Werner et al. (1996) apresentaram a faixa do teor adequado de cálcio nas plantas de capim-colonião (Panicum maximum cv. Colonião) entre 3 e $8 \mathrm{~g} / \mathrm{kg}$. As médias observadas atendem esse critério, com teores variando de 4,1 a 4,2 g/kg para doses de 0, 50 e $100 \mathrm{~kg}$ de $\mathrm{P}_{2} \mathrm{O}_{5} / \mathrm{ha}$. Os teores de cálcio reduziram com o aumento das adubações ( $\mathrm{Ne}_{2} \mathrm{O}_{5}$ ). As médias encontradas foram de 4,5; 4,3; 3,9 e 4,0 g/kg para as doses de 0,100, 200 e $300 \mathrm{~kg}$ de N/ha, provavelmente em virtude do efeito de diluição, que ocasionou aumentos significativos no rendimento forrageiro quando a gramínea foi adubada, concordando com relatos de Andrade et al. (2000), que, avaliando os efeitos das adubações nitrogenados (de 20 a $380 \mathrm{~kg}$ de $\mathrm{N} / \mathrm{ha}$ ) e potássica (de 16 a $304 \mathrm{~kg}$ de $\mathrm{K}_{2} \mathrm{O} / \mathrm{ha}$ ) no capim-elefante, observaram aumento na produtividade e redução nos teores de cálcio. Primavesi et al. (2004), em pesquisa com capim-coastcross (Cynodon dactylon), não observaram efeito da fontes nitrato de amônio e ureia nem das doses sobre os teores de cálcio.

Não houve efeito de interação das doses de nitrogênio e de $\mathrm{P}_{2} \mathrm{O}_{5}$ para o teor de fósforo, o qual apresentou comportamento quadrático em resposta às doses de nitrogênio e de $\mathrm{P}_{2} \mathrm{O}_{5}$ (Figura 1). Os teores médios foram de 3,3; 2,7; 2,4 e 2,2 g/kg, para 0, 100, 200 e $300 \mathrm{~kg}$ de $\mathrm{N} / \mathrm{ha}$, respectivamente. Os teores de fósforo reduziram com o aumento das doses de nitrogênio, o que pode ser explicado pelo efeito da diluição, apesar de se manter relativamente elevado em todos os tratamentos, em comparação ao nível adequado de 1 a 3 g/kg de fósforo descrito por Werner et al. (1996), para o capim-colonião.

Redução dos teores de fósforo com as doses de nitrogênio, também foi observada por Primavesi et al. (2004), com capim-coastcross. Moreira et al. (2005) observaram declínio nos teores de fósforo nas gramíneas Urochloa decumbens e Hyparrhenia rufa com aumento das doses de nitrogênio (0, 50, 100 e 150 kg/ha); também Ribeiro et al. (1999) observaram que os teores de fósforo em lâminas foliares e colmos de Pennisetum purpureum reduziram com o aumento das doses de nitrogênio.

As doses de nitrogênio tiveram efeito quadrático (Figura 1). As médias observadas quando se usou doses de $\mathrm{P}_{2} \mathrm{O}_{5}$ foram 3,0; 3,1 e 3,1 g/kg de $\mathrm{Mg}$ para doses de 0, 50 e $100 \mathrm{~kg}$ de $\mathrm{P}_{2} \mathrm{O}_{5} /$ ha. Em relação às doses de $\mathrm{N}$, as médias foram de 3,1; 3,0; 2,9 e 3,1 g/kg de $\mathrm{Mg}$ para as doses de 0, 100, 200 e $300 \mathrm{~kg}$ N/ha, respectivamente. Apesar da diferença estatística observada, os resultados estão muito próximos e situam-se na faixa adequados de 1 a 5 g/kg (Werner et al., 1996) para plantas de capim-colonião. Primavesi et al. (2004), trabalhando com capim-coastcross, observaram teores que variaram de 1,8 a 2,7 g/kg de Mg, de acordo com os níveis de adubação nitrogenada usados.

\section{Conclusões}

As doses de nitrogênio não afetam os teores de magnésio, mas reduzem os teores de matéria seca, cálcio e fósforo, enquanto a adubação fosfatada aumenta o teor de fósforo do capim-tanzânia. A adubação com nitrogênio e fósforo tem efeito quadrático nos teores de proteína bruta, fibra em detergente neutro e nutrientes digestíveis totais no capim-tanzânia cortado a cada 28 dias de crescimento, melhorando o valor nutritivo da forragem. 


\section{Referências}

Almeida neto, J.T. Avaliação de 30 acessos de Panicum maximum Jacq. quanto à produtividade e qualidade de sementes, estabelecidos em Itapetinga, BA. 1992, 58f. Dissertação (Mestrado em Agronomia) - Universidade Federal da Bahia, Cruz das Almas.

ANDRADE, A.C.; FONSECA, D.M.; GOMIDE, J.A. et al Produtividade e valor nutritivo do capim-elefante cv. Napier sob doses crescentes de nitrogênio e potássio. Revista Brasileira de Zootecnia, v.29, n.6, p.1589-1595, 2000.

BALSALOBRE, M.A.A.; CORSI, M.; SANTOS, P.M. et al. Composição química e fracionamento do nitrogênio e dos carboidratos do capim Tanzânia irrigado sob três níveis de resíduo pós-pastejo. Revista Brasileira de Zootecnia, v.32, n.3, p.519-528, 2003.

BRÂNCIO, P.A.; NASCIMENTO JR., D.; EUCLIDES, V.P.B. et al Avaliação de três cultivares de Panicum maximum Jacq. sob pastejo, composição química e digestibilidade da forragem. Revista Brasileira de Zootecnia, v.31, n.4, p.1605-1613, 2002.

CANTARUTTI, R.B.; ALVAREZ, V.V.H.; RIBEIRO, A.C. Amostragem de solo. In: RIBEIRO, A.C.; GUIMARÃES, P.T.G.; ALVAREZ, V.V.H. (Eds.) Recomendações para uso de corretivos e fertilizantes em Minas Gerais - $5^{\text {a }}$ aproximação. Viçosa, MG: FSEMG/UFV, 1999a. p.13-20.

CANTARUTTI, R.B.; ALVAREZ V.V.H.; RIBEIRO, A.C. Pastagens. In: RIBEIRO, A.C.; GUIMARÃES, P.T.G.; ALVAREZ V.V.H. (Eds.) Recomendações para uso de corretivos e fertilizantes em Minas Gerais - $5^{a}$ aproximação. Viçosa, MG: CFSEMG/UFV, 1999b. p.332-341.

CAPPELLE, E.R.; VALADARES FILHO, S.C.; SILVA, J.F.C. et al Estimativas do valor energético a partir de características químicas e bromatológicas dos alimentos. Revista Brasileira de Zootecnia, v.30, n.6, p.1837-1856, 2001.

DIFANTE, G.S.; EUCLIDES, V.P.B.; NASCIMENTO JR., D. et al. Desempenho e conversão alimentar de novilhos de corte em capim-tanzânia submetido a duas intensidades de pastejo sob lotação rotativa. Revista Brasileira de Zootecnia, v.39, n.1, p.33-41, 2010.

EUCLIDES, V.P.B. Valor alimentício de espécies forrageiras do gênero Panicum. In: SIMPÓSIO SOBRE MANEJO DA PASTAGEM, 12., 1995, Piracicaba. Anais... Piracicaba: FEALQ, 1995. p.245-273.

FICK, K.R.; McDOWELL, L.R.; MILES, P.H. et al. Methods of mineral analysis for plant and animal tissues. 2.ed. Gainesville: University of Florida, 1979. 90p.

FISKE, C.H.; SUBBAROW, Y. The colorimetric determination of phosphorus. Journal Biological Chemical, v.66, p.375-400, 1925.

GERDES, L.; WERNER, J.C.; COLOZZA, M.T. et al. Avaliação de características de valor nutritivo das gramíneas forrageiras Marandu, Setária e Tanzânia nas estações do ano. Revista Brasileira de Zootecnia, v.29 n.4, p.955-963, 2000.

GRANT, C.A; FLATEN, D.N. Importância do fósforo no desenvolvimento inicial da planta. Piracicaba: Potafós, 2001. p.1-5. (Informações Agronômicas, 95).
MACHADO, A.O.; CECATO, U.; MIRA, R.T. et al. Avaliação da composição química e digestibilidade in vitro da matéria seca de cultivares e acessos de Panicum maximum Jacq. sob duas alturas de corte. Revista Brasileira de Zootecnia, v.27 n.5, p.1057-1063, 1998.

MOREIRA, L.M.; FONSECA, D.M.; VÍTOR, C.M.T. et al. Renovação de pastagem degradada de capim-gordura com a introdução de forrageiras tropicais adubadas com nitrogênio ou em consórcios. Revista Brasileira de Zootecnia, v.34 n.2, p.442-453, 2005.

PATÊS, N.M.S.; PIRES, A.J.V.; CARVALHO, G.G.P. et al. Produção e valor nutritivo do capim-tanzânia fertilizado com nitrogênio e fósforo. Revista Brasileira de Zootecnia, v.37, n.11, p.1934-1939, 2008.

PRIMAVESI, A.C.; PRIMAVESI, O.; CORRÊA, L.A. et al. Adubação nitrogenada em capim coastcross: efeitos na extração de nutrientes e recuperação. Revista Brasileira de Zootecnia, v.33, n.1, p.68-78, 2004.

RIBEIRO JR., J.I. Análise estatística no SAEG. Viçosa, MG: UFV, 2001. 301p.

RIBEIRO, K.G.; GOMIDE, J.A.; PACIULLO, D.S.C. et al. Adubação nitrogenada do capim-elefante cv. Mott. 2. valor nutritivo ao atingir 80 e $120 \mathrm{~cm}$ de altura. Revista Brasileira de Zootecnia, v.28 n.6, p.1194-1202, 1999.

SANTOS, M.V.F.; DUBEUX JR., J.C.B.; SILVA, M.C. et al. Produtividade e composição química de gramíneas tropicais na Zona da Mata de Pernambuco. Revista Brasileira de Zootecnia, v.32, n.4, p.821-827, 2003.

SANTOS, P.M.; CORSI, M.; BALSALOBRE, M.A.A. Efeito da freqüência de pastejo e da época do ano sobre a produção e a qualidade em Panicum maximum cvs. Tanzânia e Mombaça. Revista Brasileira de Zootecnia, v.28, n.2, p.244-249, 1999.

SILVA, D.J.; QUEIROZ, A.C. Análise de alimentos (métodos químicos e biológicos). 3.ed. Viçosa, MG: UFV, 2002. 235p.

SOUSA, D.M.G.; LOBATO, E. Adubação com nitrogênio. In: SOUSA, D.M.G.; LOBATO, E. (Eds.) Cerrado - correção do solo e adubação. 2.ed. Brasília: EMBRAPA. 2004. p.129-145.

SOUSA, D.M.G.; LOBATO, E.; REIN, T.A. Adubação com fósforo. In: SOUSA, D.M.G.; LOBATO, E. (Eds.) Cerrado correção do solo e adubação. 2.ed. Brasília: EMBRAPA, 2004. p.147-168.

VALADARES FILHO, S.C.; ROCHA JR., V.R.; CAPPELLE, E.R. Tabelas brasileiras de composição de alimentos para bovinos. Viçosa, MG: UFV, 2002. 297p.

VAN SOEST, P.J. Nutritional ecology of the ruminant. Cowallis: O. \& Books, 1994. 476p.

VAN SOEST, P.J. Symposium on factors influencing the voluntary intake of herbage by ruminants: voluntary intake relation to chemical composition on and digestibility. Journal of Animal Science, n.24, v.3, p.834-844, 1965.

WERNER, J.C. Adubação de pastagens de Brachiaria spp. In: SIMPÓSIO SOBRE MANEJO DA PASTAGEM, 11., Piracicaba, 1994. Anais... Piracicaba: FEALQ, 1994. p.209-223.

WERNER, J.C.; PAULINO, V.T.; CANTARELLA, H. et al. Recomendações de adubação e calagem para o Estado de São Paulo. Campinas: Fundação IAC, 1996. p.263-274. (Boletim Técnico, 100). 